\title{
Current Insights into the Role of the Growth Hormone-Insulin-Like Growth Factor System in Short Children Born Small for Gestational Age
}

\author{
Judith S. Renes $^{a}$ Jaap van Doorn ${ }^{b}$ Anita C.S. Hokken-Koelega ${ }^{a, c}$ \\ a Department of Paediatrics, Subdivision of Endocrinology, Erasmus University Medical Centre, Sophia Children's \\ Hospital, Rotterdam, The Netherlands; ${ }^{b}$ Department of Genetics, Section of Metabolic Diagnostics, University \\ Medical Centre Utrecht, Utrecht University, Utrecht, The Netherlands; ' ${ }^{\mathrm{D}}$ Dutch Growth Research Foundation, \\ Rotterdam, The Netherlands
}

\section{Keywords}

Small for gestational age · Growth hormone · Insulin-like growth factor binding proteins . Acid-labile subunit .

Ternary complex formation

\begin{abstract}
Background: The reason for the insufficient catch-up growth seen in $10 \%$ of children born small for gestational age (SGA) is poorly understood. Disturbances in the growth hormone $(\mathrm{GH})$ - insulin-like growth factor (IGF) axis might underlie this failure to show sufficient catch-up growth. Conclusion: This review summarizes insights gained in the molecular and (epi) genetic mechanisms of the GH-IGF axis in short children born SGA. The most notable anomalies of the IGF system are the lowered IGF-I levels in both cord blood and the placenta, and the increased expression of IGF-binding proteins (IGFBP)-1 and IGFBP-2, which inhibit IGF-I, in the placenta of SGA neonates. These observations suggest a decreased bioactivity of IGF-I in utero. IGF-I levels remain reduced in SGA children with short stature, as well as IGFBP-3 and acid-labile subunit levels. Proteolysis of IGFBP-3 appears to be increased.

C 2019 The Author(s)

Published by S. Karger AG, Basel
\end{abstract}

\section{Introduction}

Short stature is one of the most common medical concerns in childhood. Small for gestational age (SGA) accounts for approximately $20 \%$ of all cases of short stature [1]. SGA refers to the size of an infant at birth, and is defined as a birth weight and/or birth length below the -2.0 SDS for the gestational age [2]. In order to determine whether a child is born SGA, accurate information on gestational age, birth weight and birth length is required, as well as data derived from an appropriate reference population [2]. The term intrauterine growth retardation (IUGR) is often used synonymously with the term SGA. However, IUGR is a prenatal diagnosis and refers to a deceleration of fetal growth. IUGR does not always result in SGA birth, for example, a child with IUGR in late gestation may exhibit a normal size at birth. Similarly, being born SGA does not necessarily mean that IUGR occurred. Numerous factors are associated with SGA birth, such as maternal, placental, and demographic factors $[3,4]$. However, in $40 \%$ of the children no underlying cause can be determined. Nevertheless, it is important to try and identify an underlying cause since this may have consequences for health prognosis and treatment.

\section{KARGER}

E-Mail karger@karger.com www.karger.com/hrp
Judith Renes, MD, $\mathrm{PhD}$

Department of Paediatrics, Subdivision of Endocrinology Erasmus MC, Sophia Children's Hospital

PO Box 2060, NL-3000 CB Rotterdam (The Netherlands)

E-Mail j.renes@erasmusmc.nl 
A majority of children born SGA show spontaneous catch-up growth during the first years of life. However, approximately $10 \%$ of all children born SGA fail to show sufficient catch-up growth, and will continue to have a short stature throughout childhood and adolescence [5, 6]. Without growth hormone (GH) treatment, these children will reach an adult height well below the normal range and/or their target height range [7]. The reason for this insufficient catch-up growth is poorly understood. It has been hypothesized that disturbances in the $\mathrm{GH}$-insulin-like growth factor (IGF) axis might underlie this failure to show sufficient catch-up growth [8-10].

Also, the genetic nature of short stature in SGA children is still largely unknown despite adult height being one of the most heritable human traits [11]. A small number of genetic mutations $(<1 \%)$, mainly in genes coding for proteins that are involved in the GH-IGF axis, has been found in SGA children with short stature [12-15]. Furthermore, disturbances in epigenetics, such as DNA methylation, during critical periods of intrauterine development are presumed to play a role $[16,17]$. With advances in genetics, the list of genes and epigenetic defects involved is expected to grow [18].

For over 25 years, our research group and others have been investigating children with short stature who were born SGA. This review summarizes the latest insights gained in the molecular and (epi) genetic mechanisms of the GH-IGF axis in humans, with particular focus on short children born SGA. Also, the effects of GH treatment are discussed.

\section{GH and GH Receptor}

The $\mathrm{GH}$-axis plays a critical role in many physiological processes. It is very complex and is represented schematically in Figure 1 [19]. The pulsatile secretion of GH sets a cascade in motion involving multiple organs and systems $[19,20]$. Also, the factors determining normal growth depend on a child's age. For example, intrauterine growth is not dependent on GH since infants with congenital absence of the pituitary are born normal in size. Early postnatal growth up until 6 months of age is predominantly insulin dependent [19-21]. After these first 6 months, GH becomes increasingly important in controlling longitudinal growth. Several studies have demonstrated that up to $60 \%$ of SGA children with insufficient catch-up growth show a reduction in physiological 24-h $\mathrm{GH}$ secretion and/or low GH peaks during provocation tests $[9,10]$. The reason for this is unknown.
The effects of GH can be accomplished only in the presence of a normal functioning GH receptor (GHR). The GHR gene is located on chromosome 5, and there are 2 isoforms in humans: a full-length isoform and an isoform that lacks exon 3 (d3-GHR). Polymorphisms of the d3-GHR gene are present in heterozygosis in $\sim 40 \%$ of the healthy population, and in homozygosis in $\sim 15 \%$. It results in the loss of amino acid residues 7-28 and the amino acid substitution $\mathrm{A} 6 \mathrm{D}$ at the $\mathrm{N}$-terminal part of the extracellular receptor domain [22]. In vitro, the d3-GHR polymorphism was found to enhance the signal transduction of the GHR in exposure to GH compared to the fulllength allele homodimer [23]. Several studies have shown an association between d3-GHR and increased growth response to GH treatment in children born SGA $[22,24]$. However, results regarding the exon 3 GHR polymorphism and GH responsiveness are discordant.

\section{Insulin-Like Growth Factors}

Although some of the effects of $\mathrm{GH}$ are direct actions, most effects are mediated through the peptide hormone IGF-I $[19,25]$. The IGF family includes IGF-I, IGF-II, 3 membrane bound receptors, several IGF-binding proteins (IGFBPs), and the acid-labile subunit (ALS). IGF-I and IGF-II are closely related, single chain polypeptides, which share approximately $50 \%$ of their amino-acid sequence [19]. IGF-I, but especially IGF-II, play a dominant role in early fetal development through binding to the IGF-I receptor [26-28]. However, after organogenesis, GH-dependent IGF-I bioactivity becomes more important [29]. The role of IGF-II during postnatal life remains unclear. In mice, the disruption of the paternally inherited IGF-II allele causes severe intrauterine growth restriction, whereas the disruption of the maternally inherited IGF-II allele has no effect on growth [30]. Begemann et al. [31] reported an IGF-II variant with evidence of pathogenicity in a multigenerational family with severe intrauterine and postnatal growth restriction and a Silver-Russell syndrome phenotype.

Tzschoppe et al. [32] compared the levels of IGF-I and IGF-II in umbilical cord blood between IUGR neonates, SGA neonates without IUGR and appropriate for gestational age (AGA) neonates. The concentrations of IGF-I and IGF-II in cord blood of IUGR neonates were reduced compared to those in both SGA and AGA neonates. In SGA neonates, IGF-I levels were also lower compared to AGA neonates although to a lesser extent, whereas IGF-II levels were similar. This might indicate that different mechanisms play a role in IUGR and SGA. The low levels of IGFs in IUGR neonates, as also reported by others, 


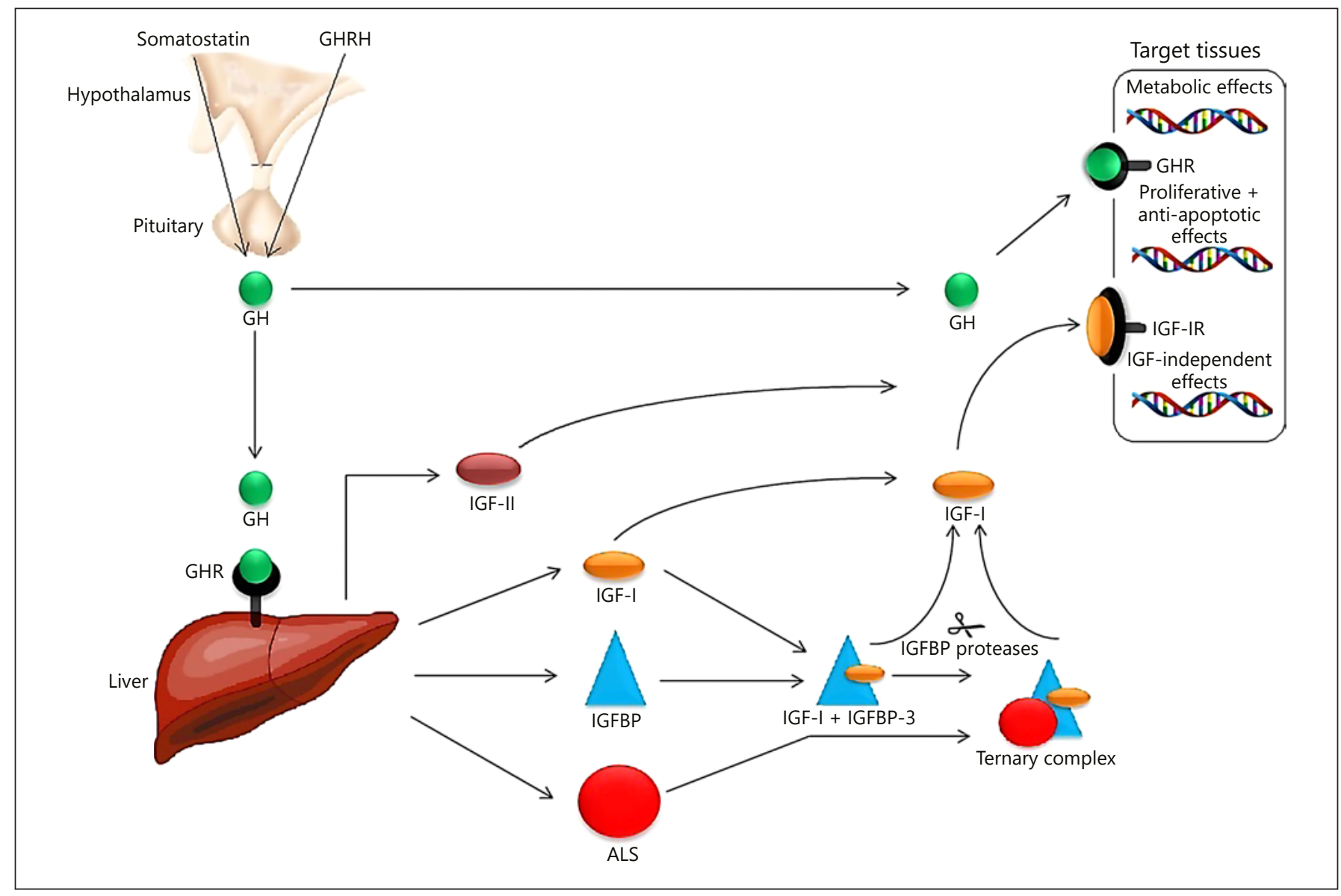

Fig. 1. Schematic view of the main components of the GH-IGF axis. $\mathrm{GH}$ releasing hormone $(\mathrm{GHRH})$ is secreted in a pulsatile manner by the hypothalamus and stimulates the secretion of $\mathrm{GH}$ by the somatotrophic cells of the anterior pituitary. Somatostatin inhibits the release of $\mathrm{GH}$. In the circulation, $\mathrm{GH}$ can be found free or bound to GH binding protein (not shown). Mutations in genes encoding GHRH, GHRH receptor (not shown), somatostatin receptor (not shown), GH, and GHR usually do not result in SGA birth. GH activates the GHR on the liver and various other target tissues. This may either result in direct, metabolic effects $\mathrm{GH}$ or indirect actions being mediated trough IGF-I. IGF-I can act in mainly an autocrine, paracrine, or endocrine fashion through binding to the IGF-IR which is expressed by nearly all cell types. IGF-II, which can also bind to the IGF-IR and at least in vitro, has similar effects as IGF-I, is not directly under the influence of GH.

might not only reflect a low birth weight per se, but could also be related to placental insufficiency $[33,34]$. The deleterious fetal environment caused by placental insufficiency could induce lasting alterations in IGF signaling. In contrast, in SGA neonates, with a physiological intrauterine growth pattern and only moderately reduced IGF-I levels, other constitutionally derived factors are involved in the regulation of the IGF system, such as epi-
The IGFs exert negative feedback on GHRH and GH secretion and positive feedback on somatostatin release. The IGFs in the circulation are strongly bound to IGFBPs. This leaves a very small fraction of IGFs in the free unbound form. IGFBPs are important for the regulation of IGF bioavailability. Under normal circumstances IGFBP-3, mainly produced by the liver, is the most abundant IGFBP in the circulation. Together with an IGF and the ALS it forms a high molecular weight ternary complex that cannot pass the blood capillaries. ALS synthesis and release is GH-dependent. Most IGFBPs can also exert IGF-independent effects. At the tissue level, IGFs can be released from the IGFBPs by the action of various IGFBP proteases. GH, growth hormone; GHRH, GH releasing hormone; GHR, GH receptor; IGF, insulin-like growth factor; IGF-IR, IGF-I receptor; IGFBP, IGF-binding proteins; ALS, acidlabile subunit [96].

genetic changes in growth-related genes [32, 34, 35]. For example, the GH-IGF-I axis can be affected by a different pattern of histone modifications of GH response elements and a changed epigenetic profile of the IGF-I gene [35]. Indeed, it has been found that the IGF1 gene promoter is hypermethylated in the placenta of SGA neonates when compared to AGA neonates, being associated with a lower level of IGF-I mRNA and protein in the SGA 
group [17]. Also, Mas-Parés et al. [36] studied the microRNA profile in umbilical cord tissue of AGA and SGA subjects and found that several umbilical cord microRNAs may be associated with catch-up growth in SGA infants.

Short children born SGA have on average low-normal serum IGF-I levels, which might be partly explained by a reduction in spontaneous $\mathrm{GH}$ secretion [9, 10, 37]. Also, several polymorphisms in the $5^{\prime}$ and $3^{\prime}$ regions of the IGF-I gene have been associated with low serum IGF-I levels and the SGA phenotype $[38,39]$. There are also a few case reports describing mutations in the IGF1 gene showing variable degrees of both pre- and postnatal growth failure, deafness, and mental retardation [40, 41].

IGF-I exerts its effects through binding to the IGF-I receptor. The IGF1R gene plays an important role in prenatal and postnatal growth. There are several case-reports describing IGF1R gene haplo insufficiency leading to severe intrauterine and postnatal growth retardation, microcephaly and various other clinical manifestations, for example, feeding problems and delayed motor and mental development, but the clinical picture is very heterogeneous $[4,41]$. In a cohort of 100 short SGA children, 2 heterozygous IGF1R deletions were found [13]. In vitro functional analysis showed similar levels of IGF1R auto phosphorylation, a tendency toward reduced total IGF1R protein expression, and reduced intracellular activation of protein kinase B compared with healthy controls. This suggests that IGF1R deletions are characterized by a lower number of IGF1 receptors on the cell surface, resulting in reduced signal transduction $[13,14]$.

\section{IGF Binding Proteins}

The majority of IGF-I is firmly bound to IGFBPs. IGFBPs play an important role in regulating the availability of IGF-I. These binding proteins act as carrier proteins, transporting IGF-I from the circulation to the target tissues and prolonging the half-life of IGF-I $[19,42]$. Six IGFBPs have been identified, and they show similar organization, mostly at the $\mathrm{NH}_{2}$ - and $\mathrm{COOH}$-terminal domains $[43,44]$. All of the IGFBPs have a similar or higher binding affinity for IGF-I than for the IGF-I receptor. This suggests that the formation of IGF-I-IGFBP complexes competes with binding of IGF-I to the IGF-I receptor [45]. In healthy subjects, most of the serum IGF-I circulates in a $150 \mathrm{kD}$ ternary complex with IGFBP-3 (and to a much lesser extent IGFBP-5) and ALS [42, 46, 47]. Only 1-5\% of IGF-I is unbound with a short half-life of 10-12 min. Figure 2 shows how proteases cleave the IGFBPs to release free IGF-I into the circulation [48].
To date, no mutations have been reported in IGFBP genes [49]. Animal IGFBP knockout studies demonstrated only minor effects on fetal and postnatal growth [50]. Studies in IGFBP transgenic mice revealed that the predominant effect of overexpression of the IGFBPs has been growth inhibition, as would be anticipated from inhibition of the actions of IGF-I and IGF-II [51, 52]. This has also been described in children with chronic renal insufficiency $[53,54]$.

IGFBPs also bind non-IGF ligands in the extracellular space, cell membrane, cytoplasm and nucleus, thereby modulating cell proliferation, survival and migration in an IGF-independent manner. In general, IGFBP activity is regulated by transcriptional mechanisms as well as by post-translational modifications and proteolysis $[55,56]$.

To our knowledge, only IGFBP-1, -2 and -3, ALS, and ternary complex formation have been studied specifically in short SGA children, and is discussed below. Since IGFBP-1 and -2 are mainly involved in metabolic signaling rather than growth, these are discussed only briefly.

\section{IGF Binding Protein-1}

IGFBP-1, predominantly produced by the liver and kidney, is an acute regulator of IGF-I bioavailability and plays an important role in glucose metabolism and homeostasis. When in a phosphorylated form, IGFBP-1 sequesters IGFs with a high affinity, thereby inhibiting their actions. The production of IGFBP- 1 is suppressed through insulin, which binds to insulin-response elements in the IGFBP-1 promoter region. So, reduced serum IGFBP-1 levels reflect high insulin levels [57].

IGFBP-1 levels in both the placenta and cord blood of SGA neonates tend to be elevated when compared with those in AGA neonates $[13,32]$. Corresponding to these changes, reduced $\mathrm{CpG}$ methylation of the promoter regions of placental IGFBP-1 in the SGA neonates was found. These findings may provide an explanation of the observed lower level of bioactive IGF in cord blood of SGA neonates, as determined by an IGF-I-specific kinase receptor activation assay [32].

Short children born SGA show increased serum insulin levels suggesting increased insulin secretion in response to peripheral insulin resistance [58-60]. In a large cohort of short SGA children and adolescents, IGFBP-1 levels significantly decreased with age and were comparable to those encountered in normal statured subjects. This may reflect a normal metabolic state despite reported higher insulin secretion [57]. In the same study, it was found that the $-575 \mathrm{G} / \mathrm{A}$ single-nucleotide polymorphism (SNP) in the promotor region of the IGFBP-1 gene
18

Horm Res Paediatr 2019;92:15-27 DOI: $10.1159 / 000502739$
Renes/van Doorn/Hokken-Koelega 
Fig. 2. Average distribution of IGFs among ternary and binary complexes and the unbound fraction in the circulation of healthy subjects. Stable ternary $150 \mathrm{kD}$ complexes are formed by an IGF, IGFBP-3 (to a lesser extent also with IGFBP-5) and ALS. In addition, there are binary $40-50 \mathrm{kD}$ complexes consisting of an IGF and an IGFBP with a relatively shorter half-life in the circulation. Only a very small fraction of the IGFs are present in the free unbound form. IGFs are released from the complexes by various types of IGFBP proteases (...) which include the (MMPs) PAPP-A2 and A. These proteases cleave IGFBP-3 and-5 (PAPPA2) and IGFBP-2, -4, and -5 (PAPP-A) and are thought to play an important role in IGFBP proteolysis. STCs inhibit the proteolytic activities of PAPP-A and PAPP$\mathrm{A} 2$, thereby resulting in decreased levels of free IGF-1 and, consequently, decreased IGF-1 signaling. MMP, matrix metalloproteinases; IGF, insulin-like growth factor; IGFBP, IGF-binding proteins; PAPP, pregnancy-associated plasma protein.

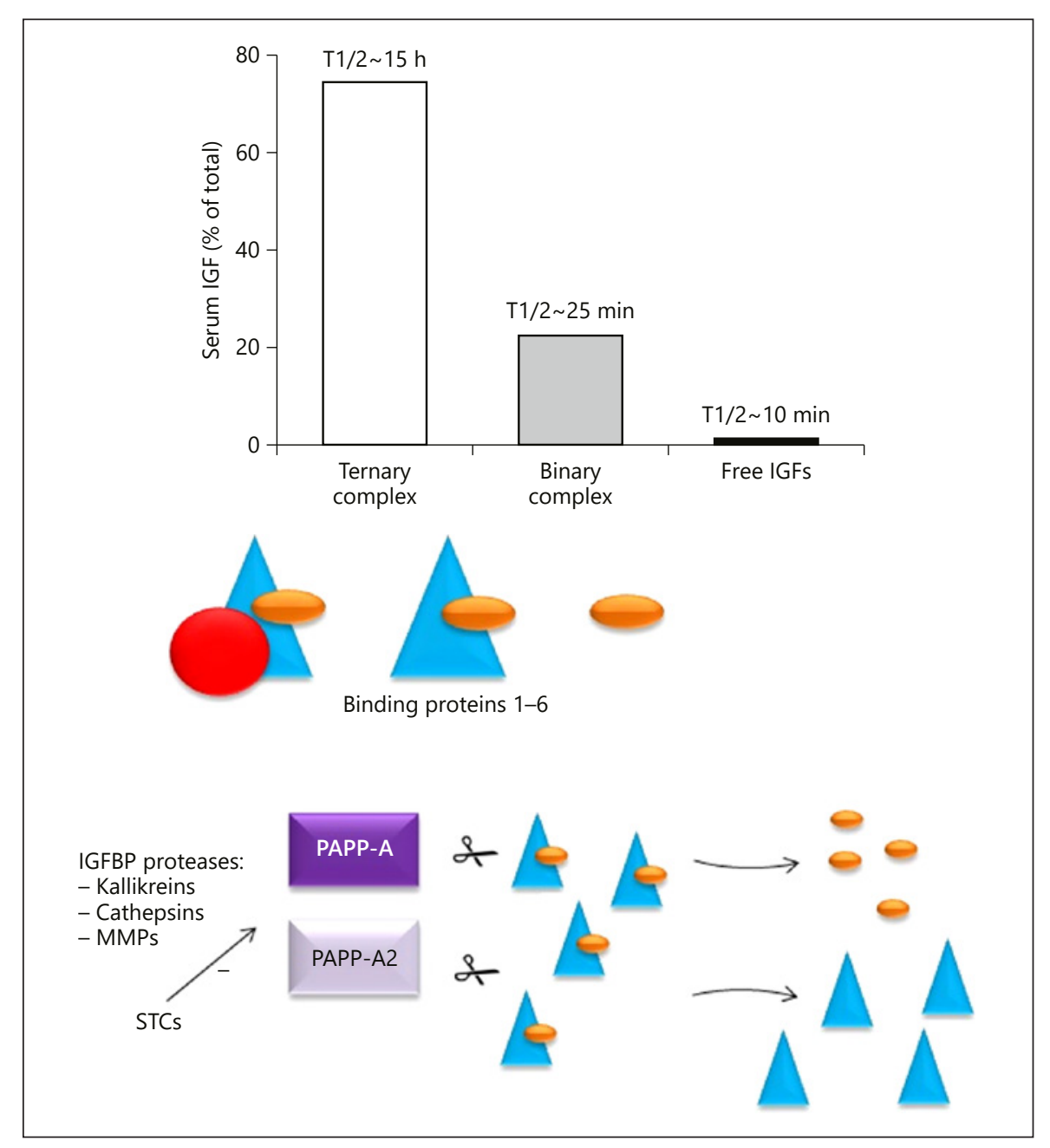

significantly affected serum IGFBP-1 levels. The levels were lowest in children carrying the more common GG genotype. The -575 G/A SNP also significantly influenced the relation between serum insulin and IGFBP-1 levels. SGA children with comparable insulin secretion and carrying the GG genotype had significantly lower serum IGFBP-1 levels (SDS) compared with SGA children carrying the AA genotype. The -575 G/A SNP is situated near at least 2 insulin response elements and could thus influence the modulation of insulin-dependent gene repression [57].

\section{IGF Binding Protein-2}

IGFBP-2 plays an important role in metabolic signaling, inflammation, and conditions such as obesity and diabetes $[61,62]$. IGFBP-2 is widely expressed during fetal development but postnatally it becomes predominantly expressed in the liver. Although an insulin-regulated element has been identified within the IGFBP-2 gene pro- moter, insulin inhibition of IGFBP-2 synthesis in vitro is far less rapid than the response of IGFBP-1 [63]. In contrast to IGFBP-1, serum concentrations of IGFBP-2 do not vary in response to meals or glucose infusions, but levels do increase after a prolonged period of fasting [64]. This indicates that the concentration of IGFBP-2 in the circulation merely reflects long-term alterations in hepatic exposure to insulin, whereas that of IGFBP-1 mirrors short-term fluctuations in insulin levels. It has been suggested that IGFBP-2 alters the activity of intracellular kinases that modulate insulin signaling in metabolically active tissues by both IGF-dependent and IGF-independent mechanisms, thereby modulating insulin sensitivity [65].

IGFBP-2 has not been extensively studied in SGA subjects. One study found that in the placenta of SGA neonates, the mRNA and protein levels of IGFBP-2 are higher compared to AGA neonates [13]. This was associated with a lower degree of $\mathrm{CpG}$ methylation of the promoter region of the IGFBP-2 gene in SGA neonates. A study in 
147 short SGA children showed that serum IGFBP-2 levels were similar compared to their normal statured peers, and did not correlate with any metabolic or cardiovascular risk factors [66].

\section{IGF Binding Protein-3}

IGFBP-3 is the main circulating carrier of IGFs in postnatal life $[67,68]$. In healthy subjects, the serum concentration of IGFBP-3 exceeds that of the other 5 binding proteins, and its affinity for IGF-I is higher than that of other binding proteins together $[68,69]$. IGFBP-3 can modulate the effects of IGF-I by controlling the amount of free IGF-I. It can suppress its transfer from the circulation to the tissues, and it can regulate the interaction between IGF-I and its receptor. IGFBP-3 also has a number of IGF-independent actions, which include inhibition of cell growth and induction of apoptosis $[68,70,71]$.

Since mutations and deletions in the genes involved in the GH-IGF-axis are uncommon in short SGA children, studies have focused on factors that might alter gene expression. Regulation of IGFBP-3 gene expression is very complex, because expression can be induced both by factors that stimulate growth (e.g., GH and insulin) and by agents that inhibit growth such as the tumor suppressor p53 (TP53). The TP53 gene encodes at least 15 protein isoforms that bind to DNA and regulate gene expression to prevent mutations of the genome. The IGFBP3 gene is a direct target of TP53, actively participating in apoptotic pathways triggered by TP53 [68]. Marzano et al. [70] reported that a member of the TP53 transcription factor family, namely, TP73, promotes IGFBP3 gene expression in actively proliferating cells. They also found that mRNA expression levels of TP73 and IGFBP3 in white blood cells are significantly lower in SGA children compared with healthy controls. The authors suggest that TP73 might be a good biomarker for assessing the risk for SGA children remaining short in adulthood.

In short SGA children, not only IGF-I but particularly IGFBP-3 levels are low (approximately -1.5 SDS) [9, 10, 37]. Low IGFBP-3 levels are very uncommon in other short statured children (except GH deficiency). These low levels could be caused by a reduction in spontaneous $\mathrm{GH}$ production, since IGFBP-3 is stabilized in serum by forming complexes with IGF-I and ALS, which are both $\mathrm{GH}$-dependent. There are also polymorphisms in the $I G F B P 3$ promoter region that have been found to correlate with IGFBP-3 levels in short SGA children [72, 73]. The $-202 \mathrm{~A} / \mathrm{C}$ SNP is located near elements involved in directing IGFBP3 promotor activity and expression and is important in regulating IGFBP-3 levels [74]. Van der
Kaay et al. [72] investigated the $-202 \mathrm{~A} / \mathrm{C}$ SNP and found that IGFBP-3 levels were highest in short SGA children carrying the AA genotype and significantly lower in children carrying the AC and CC genotype.

\section{Acid-Labile Subunit}

Another key player in IGF biology is the ALS. The amino acid sequence or structure is not related to other components of the GH-IGF system. The ALS protein is organized into 3 domains: an $\mathrm{N}$-terminal domain, a central domain containing 20 leucine-rich repeats, and $1 \mathrm{C}$-terminal domain [75-77]. David et al. [78] described a horseshoe-shaped model showing positively charged regions on the outer surface and a predominance of negatively charged regions on the inner concave surface. This may facilitate the interaction with the C-terminal region of IGFBP3, which is positively charged. The production of ALS is mostly regulated by GH, the most potent inducer of ALS mRNA in the liver [79]. The main and bestknown function of ALS is extending the half-life of IGF-I in the circulation by preventing glomerular filtration and proteolytic degradation [42].

Recently, serum ALS levels were investigated in a cohort of 312 short children born SGA [80]. Given the generally reduced IGF-I and IGFBP-3 levels in the SGA population, it was expected that mean ALS levels would also be reduced. It was shown that short SGA children tend to have lower ALS levels ( -0.5 SDS) compared to healthy controls of similar age, albeit less reduced than IGF-I and IGFBP-3 levels (<-1 SDS). It might be that the spontaneous GH secretion in short SGA children is not reduced to such an extent that the production of ALS is seriously affected, but there might also be other unknown factors involved in the secretion of ALS.

The first patient with an IGFALS gene mutation was reported in 2004 by Domené et al. [81], who described a 17-year-old boy with short stature, markedly reduced IGF-I and IGFBP-3 levels, and undetectable ALS levels. Since then several IGFALS gene mutations have been described. Patients with a homozygous IGFALS deletion or duplication have a more severe phenotype compared to patients with a compound heterozygous IGFALS mutation [81-85]. In general, children with an IGFALS mutation show only mild to moderate short stature, despite severely reduced serum IGF-I, IGFBP-3 levels, and ALS levels $[86,87]$. Subjects who are heterozygous carriers for a mutation in the IGFALS gene show approximately 1 SDS height loss when compared with wild-type individuals [88]. It has been suggested, that heterozygosity for IGFALS mutations may contribute to idiopathic short stature [89]. 


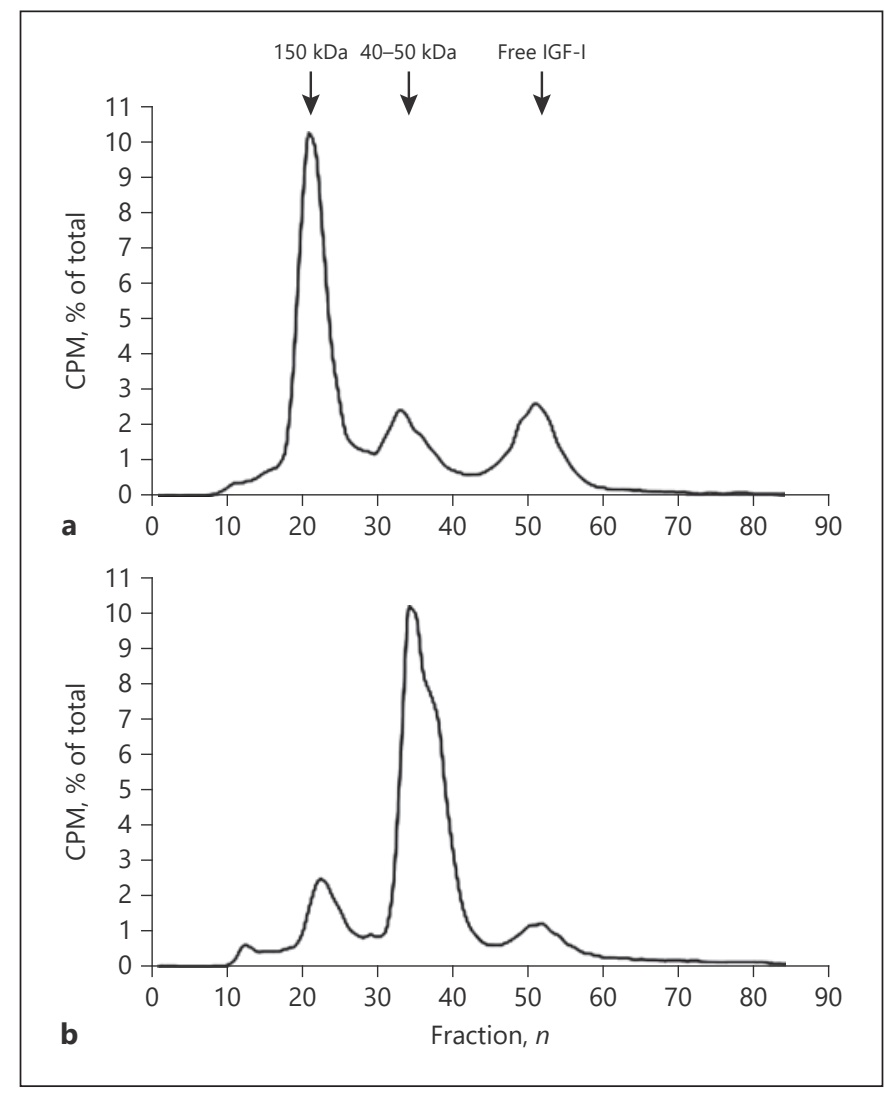

Fig. 3. Representative examples of the distribution of radioactivity among the various molecular weight size classes after (125I)-hIGFI column chromatography of pooled normal serum (a) and a subject with severely reduced ternary complex formation (b). CPM, counts per minute; $\mathrm{kD}$, kilo Dalton.

\section{Ternary Complex Formation}

One aspect of the $\mathrm{GH}$-axis that has received relatively little attention is complex formation between IGFs, IGFBP- 3 and ALS. In addition, to a minor extent, IGFBP-5 can also form a ternary complex with ALS and IGFs [90]. The formation of this ternary complex is very specific, since ALS has no affinity for free IGF-I, free IGF-II, free IGFBP-3 or free IGFBP-5 alone. This means that IGF-I (or IGF-II) must first bind to IGFBP-3 to which ALS then associates [90-92]. To efficiently form ternary complexes, there has to be a two- to threefold excess of ALS relative to IGF-I and IGFBP-3 [92]. The different molecular size classes of circulating IGF-IGFBP complexes can be determined using column chromatography after pre-incubation of ${ }^{125}$ I-IGF-I with serum (Fig. 3) [47]. This method can be used as a functional test in assessing IGF-IGFBP complex formation, for example, in patients with an IGFALS gene deletion or mutation [82].

The GH-IGF System in Short Children Born SGA
Recently, we published normative data on the distribution of ${ }^{125}$ I-IGF-I ternary ( $\left.150 \mathrm{kD}\right)$ and ${ }^{125}$ I-IGF-I binary $40-50 \mathrm{kD}$ complexes for healthy normal statured children, adolescents and young adults [47]. In the circulation of both young healthy boys and girls relatively less ${ }^{125} \mathrm{I}$-IGF-I is sequestered into ternary complexes, but this increases significantly with age. This age dependency might be partially explained by the age-related and puberty-related increase in IGFs, IGFBP-3, and ALS levels and decrease in IGFBP-1 levels.

Little is known about ternary complex formation in short children born SGA. In a cohort of 40 short SGA children ${ }^{125}$ I-IGF-I complex formation was studied. It appeared that short SGA children showed a lower ${ }^{125} \mathrm{I}$ IGF-I-150 kD complex to ${ }^{125}$ I-IGF-I-40-50 kD ratio compared to age matched healthy controls [47]. This may have been the result of higher IGF-II levels (1.4 vs. 0.1 SDS) and IGFBP-1 levels (0.6 vs. -0.2 SDS) in the short SGA children compared to the healthy controls. In the same study, height SDS in short SGA children was positively correlated with the amount of ${ }^{125}$ I-IGF-I trapped in the $150 \mathrm{kD}$ complex. Interestingly, children with a height below or equal to the -3 SDS showed lower $150 \mathrm{kD}$ complex formation compared with short SGA children with a height between the -3 and -2 SDS [47].

${ }^{125}$ I-IGF-I column chromatography is an ex vivo method of assessing ternary complex formation. To further investigate the reduced ternary complex formation in young healthy children, we determined whether endogenous IGF-I was indeed less present in the $150 \mathrm{kD}$ ternary complex, by performing neutral chromatography, without addition of ${ }^{125} \mathrm{I}$-IGF-I. This showed that most of the IGF-I was still present in the $150 \mathrm{kD}$ ternary complex, even in those with severely reduced ${ }^{125}$ I-IGF-I ternary complex formation. Subsequent investigations showed that young healthy children had higher levels of proteolysed IGFBP-3 $(29 \mathrm{kD})$, which cannot bind ${ }^{125} \mathrm{I}-$ IGF-I and thus results in reduced ${ }^{125}$ I-IGF-I $150 \mathrm{kD}$ complex formation. This is a similar phenomenon as previously described in the serum of pregnant women [93]. In addition, our data showed that young healthy children had considerable IGFBP-3 proteolytic activity, which declined with age. Since proteolysed IGFBP-3 appears to bind unlabeled, endogenous IGF-I with a lower affinity than intact IGFBP-3, it is hypothesized that IGF-I can be released more easily from $29 \mathrm{kD}$ IGFBP-3 enriched 150 $\mathrm{kD}$ complexes [94]. The correlation between height SDS and ${ }^{125}$ I-IGF-I-150 kD complex formation in short SGA children presumably reflects a complicated relationship 
between GH, IGF-I, IGFBP-3, ALS, and also IGFBP-3 proteolysis [47]. Which protease(s) are involved here remains to be elucidated.

\section{IGFBP-3 Proteolysis}

For IGF-I to exert its biological effects it must be released from its binding proteins. One important mechanism for this is proteolysis of IGFBPs. Three classes of IGFBP proteases have been recognized. These include kallikreins, cathepsins, and matrix metalloproteinases [95]. They have been shown to cleave IGFBP-2 to -6 with varying specificity. Using protein sequencing and specific protease inhibitors, several proteases have been identified that are capable of cleaving specifically IGFBP-3, such as the kalikrein-like prostate-specific antigen and matrix metalloproteinases pregnancy-associated plasma protein-A2 (PAPP-A2) $[45,95,96]$. Proteases are capable of cleaving 42-40 kD IGFBP-3 into $29 \mathrm{kD}$ and smaller fragments, as revealed after SDS gel electrophoresis, which have a significantly reduced affinity for IGF-I, resulting in destabilisation of the ternary complex and an increased bioavailability of IGF-I to target tissues [94, 96, 97]. Another related metalloproteinase, PAPP-A, specifically cleaves IGFBP-2, IGFBP-4, and IGFBP-5 and is now known to be widely expressed in multiple tissues [96]. Stanniocalcins (STCs), widely expressed proteins involved in calcium and phosphate metabolism, have been shown to inhibit the activities of these metalloproteinases. STC1 inhibits mainly PAPP-A, whereas STC2 affects PAPP-A2 [98, 99]. The physiological roles of the STCs in the IGF system and possibly SGA warrant further investigations.

IGFBP-3 proteolysis was first described in pregnant women, in whom almost all circulating IGFBP-3 is proteolysed, particularly in the third trimester $[93,100,101]$. Since then, proteolytic fragments of IGFBP-3 have been detected in sera of newborns, children with IUGR, acute illness, and GH-deficient patients [102-104]. Cianfarani et al. [104] determined IGFBP-3 circulating molecular forms in approximately 70 patients with GH deficiency and 60 subjects with idiopathic short stature. Their results showed that patients with GH deficiency have increased IGFBP-3 proteolytic activity, which was absent in all children with idiopathic short stature. Although spontaneous GH secretion is reduced in short SGA children, none of the short SGA children investigated by us could be classified as GH deficient $[9,10]$. Nonetheless, it was shown that they also have a higher level of proteolysed $29 \mathrm{kD}$ IGFBP-3 in their serum compared with healthy controls (35.1 vs. $12.2 \%$ ), indicating a higher IGFBP-3 proteolytic activity [47]. This has led to the sug- gestion that increased IGFBP-3 proteolytic activity in short SGA children merely represents a mechanism that attempts to compensate for the lower biological activity of IGF-I that nevertheless fails to induce adequate catchup growth [103]. This is supported by the recent finding that in healthy normal statured children, IGFBP-3 proteolytic activity only appears to be increased during the first years of life $[45,100]$. During these first years growth velocity is the highest, although IGF-I levels are relatively low. To ensure bioavailability of IGF-I to target tissues, IGFBP-3 proteolytic activity must be increased. Thus, in conditions were IGF-I levels are (relatively) low, a protease system is active, resulting in proteolysis of IGFBP-3, which enhances the release of IGF-I from the ternary complex.

Until recently, there were no mutations described in genes encoding proteases that are capable of cleaving IGFBPs. However, Dauber et al. [105] described 5 children of 2 unrelated families, 2 of whom were born SGA, with progressive growth failure, moderate microcephaly and thin long bones due to loss of function mutation in the PAPPA2 gene. Whole-exome sequencing identified 2 different homozygous variants in the PAPPA2 gene. Functional studies showed loss of PAPPA2 function resulting in high circulating serum levels of total IGF-I, IGFBP-3, IGFBP-5, and ALS. Size-exclusion chromatography showed a significant increase in ternary complex formation. However, the increase in IGF-I was not accompanied by an elevated IGF bioactivity (i.e., the ability of IGF-I to phosphorylate the IGF-receptor). Free and bioactive IGF-I levels were low or in the low-normal range with a marked decrease in the bioactive/IGF-I ratio. It was suggested that this relative decrease in IGF bioactivity was due to an inability of the abnormal PAPP-A2 to release IGF-I from its binding proteins by proteolysis. Apparently, PAPP-A2 deficiency plays a role in stagnating growth in a subpopulation of short SGA patients that differs from the cohorts studied by us. Interestingly, treatment of 2 PAPP-A2 deficient siblings with rIGF-I for 1 year resulted in a clear increase in growth velocity (2.1 and 3.1 SDS) and height SDS (0.4 SDS in both children) [106].

\section{GH Treatment and Effect of Treatment}

Recombinant GH has been used since 1986 and has replaced GH extracted from human pituitaries. The indications for GH treatment have gradually extended from 
replacement therapy in children with GH deficiency to conditions in which short stature is not due to GH deficiency, including short stature in children born SGA. Various high-quality clinical trials on the effects of $\mathrm{GH}$ treatment have shown that most short children born SGA show catch-up growth during GH treatment with an significant improvement in adult height expressed as SDS [107-111]. Since 2003, GH treatment for short children born SGA has been registered in Europe, the United States, and Japan.

Children born SGA comprise a heterogeneous group with a broad spectrum of clinical characteristics, and before starting $\mathrm{GH}$ treatment a thorough endocrine evaluation of a short infant presenting with SGA is necessary to exclude hypothyroidism, celiac disease, malnutrition, renal failure or chronic inflammation. Especially the latter condition has been associated with abnormalities in the GH/IGF-I axis, including GH/IGF-I insufficiency, GH/IGF-I resistance, down regulation of GH/IGF-I receptors, disruption in downstream GH/ IGF-I signaling pathways and dysregulation of IGFBPs $[112,113]$. Interactions between proinflammatory cytokines, such as interleukin 6, and the IGF system seem to be important factors for the onset of these abnormalities. In fact, it has been proposed that IUGR shares features with conditions characterized by chronic inflammation [112, 114].

Although GH therapy is effective in increasing adult height in short SGA children, the variability in catch-up growth is high [107]. Because of rising healthcare costs, it is becoming increasingly important to identify short children who will benefit from long-term GH treatment. It has been shown that, among others, young age at start of treatment, GH dose and IGFBP-3 levels are important determinants of GH treatment response [115-117]. However, even after accounting for these variables, there remains a wide variation, which is difficult to explain. Animal data suggest that the presence of sufficient ALS in serum is required for maximal effectiveness of exogenous GH [118]. Also, it has been shown that serum ALS levels at start of GH treatment are positively correlated with height SDS at start of puberty [80]. De Ridder et al. [116] described a prediction model for height SDS at onset of puberty. Adding ALS to this prediction model resulted in a moderate improvement (5\%) in accuracy. As with all variables, the contribution of ALS to the prediction model was modest. However, it suggests that determining serum ALS at start of GH treatment may contribute to a slightly more accurate prediction of the growth response to $\mathrm{GH}$ treatment.

The GH-IGF System in Short Children Born SGA
Whether GH treatment affects IGFBP-3 proteolysis is not clear since contradictory results have been reported [119-121]. IGFBP-3 proteolytic activity was assessed in sera of short SGA children after 1 year of GH treatment [47]. This study showed no increased IGFBP-3 proteolysis, while, ${ }^{125}$ I-IGF-I ternary complex formation, serum IGF-I levels, and growth velocity increased significantly. These findings suggest that GH treatment induces sufficiently high serum IGF-I levels to stimulate growth. Conversely, it has been shown that during GH treatment, IGFI levels above the 1 SDS are not unusual in short children born SGA [37, 122]. These high IGF-I levels are a concern and often subject of debate because of the unknown longterm consequences [123]. It has been suggested that IGFbioactivity is a more sensitive method for monitoring the effects of GH treatment than immunoreactive serum IGFI levels. In children with Prader-Willi syndrome, Bakker et al. [124] showed that despite high, GH-induced, immunoreactive serum IGF-I levels, there was no difference in IGF-bioactivity compared to untreated healthy controls, which is reassuring. There are, however, no data on IGFbioactivity in short SGA children treated with GH.

\section{Conclusions}

As the GH-IGF axis is involved in many physiological processes, understanding its molecular and (epi) genetic regulation is fundamental in optimizing our knowledge of the aetiology of the SGA phenotype. The most notable abnormalities of the IGF system in SGA neonates are the lowered levels of IGF-I in both cord blood and the placenta of SGA neonates. In contrast, the expression of the IGF-I inhibiting IGFBP-1 and IGFBP-2 in the placenta of SGA neonates is increased compared to AGA neonates. These observations suggest a decreased bioactivity of IGF-I in utero in SGA neonates. IGF-I levels remain reduced in SGA children with short stature, as well as those of IGFBP-3 and ALS. IGFBP-3 in the circulation of short SGA children appears to be subject to proteolysis to a higher degree than normal. Proteolyzed IGFBP-3 can, just like IGFBP-3, form ternary complexes with ALS and IGFs. However, it is assumed that the IGFs are bound in these complexes with a lower affinity and thus may be released easier. The biological significance of this remains uncertain but may indicate a compensatory mechanism for the lower IGF-Ilevels in short SGA children to enhance IGF-I bioavailability. However, in contrast, in 2 short SGA children an inactivating mutation in one of the IGFBP-3 proteases, PAPPA-2, has been found, leading to enhanced levels of IGF-I,

Horm Res Paediatr 2019;92:15-27 
IGFBP-3, and ALS. It is not clear whether this concerns 2 exceptional cases of SGA. Further studying of IGFBP-3 proteolysis and the determination of the IGF bioactivity in serum of short SGA children is needed [125].

The lack of a clear identifiable cause of short stature in most SGA children renders an etiopathological approach to therapy difficult. Increasing our knowledge of the variability of the SGA phenotype is not only important for diagnosis but also for treatment options and expectations regarding the growth response. Pharmacogenetic studies might clarify some of the wide variation in growth response. Also, there is a necessity to optimize the GH dosage, since this will help to improve growth results. By using advanced growth prediction models, it might become feasible to decide on an individual GH dosage from start of treatment, thereby aiming for the best treatment options for each individual child. Further research is needed and clinical and basic researchers must continue working closely together to achieve advancements in this field.

\section{Statement of Ethics}

The authors have no ethical conflicts to disclose.

\section{Disclosure Statement}

A.C.S.H.-K. received an independent research grant from Novo Nordisk BV (The Netherlands) for the investigator-initiated studies. The remaining authors have nothing to disclose.

\section{Author Contributions}

J.S.R.: main author, made a substantial contribution to the conception, design and drafted the article and approved the final version. J.D. made a substantial contribution to the conception and design of the article, critically revised the content of the article and approved the final version. A.C.S.H.-K. made a substantial contribution to the conception and design of the article, critically revised the content of the article and approved the final version.

\section{References}

1 Karlberg J, Albertsson-Wikland K. Growth in full-term small-for-gestational-age infants: from birth to final height. Pediatr Res. 1995 Nov;38(5):733-9.

2 Clayton PE, Cianfarani S, Czernichow P, Johannsson G, Rapaport R, Rogol A. Management of the child born small for gestational age through to adulthood: a consensus statement of the International Societies of Pediatric Endocrinology and the Growth Hormone Research Society. J Clin Endocrinol Metab. 2007 Mar;92(3):804-10.

3 Bryan SM, Hindmarsh PC. Normal and abnormal fetal growth. Horm Res. 2006;65 Suppl 3:19-27.

4 Finken MJ, van der Steen M, Smeets CC, Walenkamp MJ, de Bruin C, Hokken-Koelega AC, et al. Children Born Small for Gestational Age: Differential Diagnosis, Molecular Genetic Evaluation, and Implications. Endocr Rev. 2018 Dec;39(6):851-94.

5 Hokken-Koelega AC, De Ridder MA, Lemmen RJ, Den Hartog H, De Muinck KeizerSchrama SM, Drop SL. Children born small for gestational age: do they catch up? Pediatr Res. 1995 Aug;38(2):267-71.

6 Albertsson-Wikland K, Boguszewski M, Karlberg J. Children born small-for-gestational age: postnatal growth and hormonal status. Horm Res. 1998;49 Suppl 2:7-13.

7 Chaussain JL, Colle M, Ducret JP. Adult height in children with prepubertal short stature secondary to intrauterine growth retardation. Acta Paediatr Suppl. 1994 Apr;399 s399:72-3.

8 Stanhope R, Ackland F, Hamill G, Clayton J, Jones J, Preece MA. Physiological growth hor- mone secretion and response to growth hormone treatment in children with short stature and intrauterine growth retardation. Acta Paediatr Scand Suppl. 1989;349 s349:47-52.

9 de Waal WJ, Hokken-Koelega AC, Stijnen T, de Muinck Keizer-Schrama SM, Drop SL; The Dutch Working Group on Growth Hormone. Endogenous and stimulated GH secretion, urinary GH excretion, and plasma IGF-I and IGF-II levels in prepubertal children with short stature after intrauterine growth retardation. Clin Endocrinol (Oxf). 1994 Nov; 41(5):621-30.

10 Boguszewski M, Rosberg S, Albertsson-Wikland K. Spontaneous 24-hour growth hormone profiles in prepubertal small for gestational age children. J Clin Endocrinol Metab. 1995 Sep;80(9):2599-606.

11 Visscher PM, Hill WG, Wray NR. Heritability in the genomics era-concepts and misconceptions. Nat Rev Genet. 2008 Apr;9(4):255-66.

12 Walenkamp MJ, Wit JM. Single gene mutations causing SGA. Best Pract Res Clin Endocrinol Metab. 2008 Jun;22(3):433-46.

13 Ester WA, van Duyvenvoorde HA, de Wit CC, Broekman AJ, Ruivenkamp CA, Govaerts LC, et al. Two short children born small for gestational age with insulin-like growth factor 1 receptor haploinsufficiency illustrate the heterogeneity of its phenotype. J Clin Endocrinol Metab. 2009 Dec;94(12):4717-27.

14 Veenma DC, Eussen HJ, Govaerts LC, de Kort SW, Odink RJ, Wouters $\mathrm{CH}$, et al. Phenotypegenotype correlation in a familial IGF1R microdeletion case. J Med Genet. 2010 Jul;47(7): 492-8.
15 van der Steen M, Pfundt R, Maas SJ, Bakkervan Waarde WM, Odink RJ, Hokken-Koelega AC. ACAN Gene Mutations in Short Children Born SGA and Response to Growth Hormone Treatment. J Clin Endocrinol Metab. 2017 May;102(5):1458-67.

16 Hussain N. Epigenetic influences that modulate infant growth, development, and disease. Antioxid Redox Signal. 2012 Jul;17(2):224-36.

17 Nawathe AR, Christian M, Kim SH, Johnson M, Savvidou MD, Terzidou V. Insulin-like growth factor axis in pregnancies affected by fetal growth disorders. Clin Epigenetics. 2016 Jan;8:11.

18 Hauer NN, Popp B, Schoeller E, Schuhmann S, Heath KE, Hisado-Oliva A, et al. Clinical relevance of systematic phenotyping and exome sequencing in patients with short stature. Genet Med. 2018 Jun;20(6):630-8.

19 Le Roith D, Bondy C, Yakar S, Liu JL, Butler A. The somatomedin hypothesis: 2001. Endocr Rev. 2001 Feb;22(1):53-74.

20 Isaksson OG, Lindahl A, Nilsson A, Isgaard J. Mechanism of the stimulatory effect of growth hormone on longitudinal bone growth. Endocr Rev. 1987 Nov;8(4):426-38.

21 Hindmarsh P, Brook C. Normal growth and its endocrine control. In: Brook CG, editor. Clinical Paediatric Endocrinology. Oxford: Blackwell Scientific Publications; 1989. pp. 57-73.

22 de Graaff LC, Meyer S, Els C, Hokken-Koelega AC. GH receptor d3 polymorphism in Dutch patients with MPHD and IGHD born small or appropriate for gestational age. Clin Endocrinol (Oxf). 2008 Jun;68(6):930-4. 
23 Dos Santos C, Essioux L, Teinturier C, Tauber $\mathrm{M}$, Goffin V, Bougnères $\mathrm{P}$. A common polymorphism of the growth hormone receptor is associated with increased responsiveness to growth hormone. Nat Genet. $2004 \mathrm{Jul}$; 36(7):720-4.

24 Wegmann MG, Thankamony A, Roche E, Hoey H, Kirk J, Shaikh G, et al. The exon3deleted growth hormone receptor gene polymorphism (d3-GHR) is associated with insulin and spontaneous growth in short SGA children (NESGAS). Growth Horm IGF Res. 2017 Aug;35:45-51.

25 Le Roith D, Scavo L, Butler A. What is the role of circulating IGF-I? Trends Endocrinol Metab. 2001 Mar;12(2):48-52.

26 Han VK, D'Ercole AJ, Lund PK. Cellular localization of somatomedin (insulin-like growth factor) messenger RNA in the human fetus. Science. 1987 Apr;236(4798):193-7.

27 Randhawa R, Cohen P. The role of the insulin-like growth factor system in prenatal growth. Mol Genet Metab. 2005 Sep-Oct; 86(1-2):84-90.

28 Constância M, Hemberger M, Hughes J, Dean W, Ferguson-Smith A, Fundele R, et al. Placental-specific IGF-II is a major modulator of placental and fetal growth. Nature. 2002 Jun; 417(6892):945-8.

29 Oliver MH, Harding JE, Breier BH, Gluckman PD. Fetal insulin-like growth factor (IGF)-I and IGF-II are regulated differently by glucose or insulin in the sheep fetus. Reprod Fertil Dev. 1996;8(1):167-72.

30 DeChiara TM, Efstratiadis A, Robertson EJ. A growth-deficiency phenotype in heterozygous mice carrying an insulin-like growth factor II gene disrupted by targeting. Nature. 1990 May;345(6270):78-80.

31 Begemann M, Zirn B, Santen G, Wirthgen E, Soellner L, Büttel HM, et al. Paternally Inherited IGF2 Mutation and Growth Restriction. N Engl J Med. 2015 Jul;373(4):349-56.

32 Tzschoppe A, Riedel C, von Kries R, Struwe E, Rascher W, Dörr HG, et al. Differential effects of low birthweight and intrauterine growth restriction on umbilical cord blood insulin-like growth factor concentrations. Clin Endocrinol (Oxf). 2015 Nov;83(5):739-45.

33 Orbak Z, Darcan S, Coker M, Gökșen D. Maternal and fetal serum insulin-like growth factor-I (IGF-I) IGF binding protein-3 (IGFBP-3), leptin levels and early postnatal growth in infants born asymmetrically small for gestational age. J Pediatr Endocrinol Metab. 2001 Sep-Oct;14(8):1119-27.

34 Gicquel C, Le Bouc Y. Hormonal regulation of fetal growth. Horm Res. 2006;65 Suppl 3:28-33.

35 Álvarez-Nava F, Lanes R. GH/IGF-1 Signaling and Current Knowledge of Epigenetics; a Review and Considerations on Possible Therapeutic Options. Int J Mol Sci. 2017 Oct; 18(10):E1624.

36 Mas-Parés B, Xargay-Torrent S, Bonmatí A, Lizarraga-Mollinedo E, Martínez-Calcerrada JM, Carreras-Badosa G, et al. Umbilical cord microRNA in small-for-gestational age chil- dren and association with catch-up growth: a pilot study. J Clin Endocrinol Metab. 2019, Epub ahead of print.

37 Sas T, de Waal W, Mulder P, Houdijk M, Jansen M, Reeser M, et al. Growth hormone treatment in children with short stature born small for gestational age: 5-year results of a randomized, double-blind, dose-response trial. J Clin Endocrinol Metab. 1999 Sep;84(9):3064-70.

38 Arends N, Johnston L, Hokken-Koelega A, van Duijn C, de Ridder M, Savage M, et al. Polymorphism in the IGF-I gene: clinical relevance for short children born small for gestational age (SGA). J Clin Endocrinol Metab. 2002 Jun;87(6):2720.

39 Johnston LB, Dahlgren J, Leger J, Gelander L, Savage MO, Czernichow P, et al. Association between insulin-like growth factor I (IGF-I) polymorphisms, circulating IGF-I, and preand postnatal growth in two European small for gestational age populations. J Clin Endocrinol Metab. 2003 Oct;88(10):4805-10.

40 Netchine I, Azzi S, Le Bouc Y, Savage MO. IGF1 molecular anomalies demonstrate its critical role in fetal, postnatal growth and brain development. Best Pract Res Clin Endocrinol Metab. 2011 Feb;25(1):181-90.

41 Walenkamp MJ, Losekoot M, Wit JM. Molecular IGF-1 and IGF-1 receptor defects: from genetics to clinical management. Endocr Dev. 2013;24:128-37.

42 Zapf J, Hauri C, Futo E, Hussain M, Rutishauser J, Maack CA, et al. Intravenously injected insulin-like growth factor (IGF) I/IGF binding protein-3 complex exerts insulin-like effects in hypophysectomized, but not in normal rats. J Clin Invest. 1995 Jan;95(1):179-86.

43 Baxter RC, Martin JL, Beniac VA. High molecular weight insulin-like growth factor binding protein complex. Purification and properties of the acid-labile subunit from human serum. J Biol Chem. 1989 Jul;264(20):11843-8.

44 Jones JI, Clemmons DR. Insulin-like growth factors and their binding proteins: biological actions. Endocr Rev. 1995 Feb;16(1):3-34.

45 Bunn RC, Fowlkes JL. Insulin-like growth factor binding protein proteolysis. Trends Endocrinol Metab. 2003 May-Jun;14(4):176-81.

46 Baxter RC, Dai J. Purification and characterization of the acid-labile subunit of rat serum insulin-like growth factor binding protein complex. Endocrinology. 1994 Feb;134(2):848-52.

47 Renes IS, van Doorn J, Hokken-Koelega AC. Ternary complex formation and IGFBP-3 proteolytic activity during childhood: age-dependent changes. J Clin Endocrinol Metab. 2014 Oct;99(10):E1988-96.

48 Hizuka N, Takano K, Asakawa K, Sukegawa I, Fukuda I, Demura H, et al. Measurement of free form of insulin-like growth factor I in human plasma. Growth Regul. 1991 Jun;1(2): 51-5.

49 Rotwein P. Large-scale analysis of variation in the insulin-like growth factor family in humans reveals rare disease links and common polymorphisms. J Biol Chem. 2017 Jun; 292(22):9252-61.
50 Ning Y, Schuller AG, Bradshaw S, Rotwein P, Ludwig T, Frystyk J, et al. Diminished growth and enhanced glucose metabolism in triple knockout mice containing mutations of insulin-like growth factor binding protein-3, -4 , and -5. Mol Endocrinol. 2006 Sep;20(9): 2173-86.

51 Lofquist C, Chen J, Connor KM, Smith AC, Aderman CM, Liu N, et al. IGFBP3 suppresses retinopathy through suppression of oxygen-induced vessel loss and promotion of vascular regrowth. Proc Natl Acad Sci USA. 2007 Jun;104(25):10589-94.

52 Silha JV, Murphy LJ. Insights from insulinlike growth factor binding protein transgenic mice. Endocrinology. 2002 Oct;143(10): 3711-4.

53 Hokken-Koelega AC, Stijnen T, De Jong MC, Donckerwolcke RA, De Muinck Keizer-Schrama SM, Blum WF, et al. Double blind trial comparing the effects of two doses of growth hormone in prepubertal patients with chronic renal insufficiency. J Clin Endocrinol Metab. 1994 Oct;79(4):1185-90.

54 Rabkin R, Schaefer F. New concepts: growth hormone, insulin-like growth factor-I and the kidney. Growth Horm IGF Res. 2004 Aug; 14(4):270-6.

55 Bach LA. Insulin-Like Growth Factor Binding Proteins-an Update. Pediatr Endocrinol Rev. 2015 Dec;13(2):521-30.

56 Bach LA. What Happened to the IGF Binding Proteins? Endocrinology. 2018 Feb;159(2): 570-8.

57 van der Kaay D, Deal C, de Kort S, Willemsen R, Leunissen R, Ester W, et al. Insulin-like growth factor-binding protein-1: serum levels, promoter polymorphism, and associations with components of the metabolic syndrome in short subjects born small for gestational age. J Clin Endocrinol Metab. 2009 Apr; 94(4):1386-92.

58 Cutfield WS, Hofman PL, Vickers M, Breier B, Blum WF, Robinson EM. IGFs and binding proteins in short children with intrauterine growth retardation. J Clin Endocrinol Metab. 2002 Jan; 87(1):235-9.

59 Kerkhof GF, Hokken-Koelega AC. Rate of neonatal weight gain and effects on adult metabolic health. Nat Rev Endocrinol. 2012 Nov; 8(11):689-92.

60 Woods KA, van Helvoirt M, Ong KK, Mohn A, Levy J, de Zegher F, et al. The somatotropic axis in short children born small for gestational age: relation to insulin resistance. Pediatr Res. 2002 Jan;51(1):76-80.

61 Shin M, Kang HS, Park JH, Bae JH, Song DK Im SS. Recent Insights into Insulin-Like Growth Factor Binding Protein 2 Transcriptional Regulation. Endocrinol Metab (Seoul). 2017 Mar;32(1):11-7.

62 Street ME, Ziveri MA, Spaggiari C, Viani I, Volta C, Grzincich GL, et al. Inflammation is a modulator of the insulin-like growth factor (IGF)/IGF-binding protein system inducing reduced bioactivity of IGFs in cystic fibrosis. Eur J Endocrinol. 2006 Jan;154(1):47-52. 
63 Brown AL, Rechler MM. Cloning of the rat insulin-like growth factor-binding protein-2 gene and identification of a functional promoter lacking a TATA box. Mol Endocrinol. 1990 Dec;4(12):2039-51.

64 Clemmons DR, Snyder DK, Busby WH Jr. Variables controlling the secretion of insulinlike growth factor binding protein-2 in normal human subjects. J Clin Endocrinol Metab. 1991 Oct;73(4):727-33.

65 Wheatcroft SB, Kearney MT. IGF-dependent and IGF-independent actions of IGF-binding protein-1 and -2: implications for metabolic homeostasis. Trends Endocrinol Metab. 2009 May;20(4):153-62.

66 de Kort SW, van Doorn J, van de Sande AG, Leunissen RW, Hokken-Koelega AC. Serum insulin-like growth factor-binding protein-2 levels and metabolic and cardiovascular risk factors in young adults and children born small for gestational age. J Clin Endocrinol Metab. 2010 Feb;95(2):864-71.

67 Clemmons DR. Value of insulin-like growth factor system markers in the assessment of growth hormone status. Endocrinol Metab Clin North Am. 2007 Mar;36(1):109-29.

68 Ranke MB. Insulin-like growth factor binding-protein-3 (IGFBP-3). Best Pract Res Clin Endocrinol Metab. 2015 Oct;29(5):701-11.

69 Conover CA, Clarkson JT, Bale LK. Factors regulating insulin-like growth factor-binding protein-3 binding, processing, and potentiation of insulin-like growth factor action. Endocrinology. 1996 Jun;137(6):2286-92.

70 Marzano F, Ventura A, Caratozzolo MF, Aiello I, Mastropasqua F, Brunetti G, et al. The p53 family member p73 modulates the proproliferative role of IGFBP3 in short children born small for gestational age. Mol Biol Cell. 2015 Aug;26(15):2733-41.

71 Bach LA. IGF-binding proteins. J Mol Endocrinol. 2018 Jul;61(1):T11-28.

72 van der Kaay DC, Hendriks AE, Ester WA, Leunissen RW, Willemsen RH, de Kort SW, et al. Genetic and epigenetic variability in the gene for IGFBP-3 (IGFBP3): correlation with serum IGFBP-3 levels and growth in short children born small for gestational age. Growth Horm IGF Res. 2009 Jun;19(3):198205.

73 Faienza MF, Marzano F, Ventura AM, Wasniewska M, Valenzise M, Valletti A, et al. Regulation of IGFBP3 gene expression in short children born small for gestational age. Growth Horm IGF Res. 2011 Dec;21(6):349-55.

74 Deal C, Ma J, Wilkin F, Paquette J, Rozen F, $\mathrm{Ge} B$, et al. Novel promoter polymorphism in insulin-like growth factor-binding protein-3: correlation with serum levels and interaction with known regulators. J Clin Endocrinol Metab. 2001 Mar;86(3):1274-80.

75 Boisclair YR, Seto D, Hsieh S, Hurst KR, Ooi GT. Organization and chromosomal localization of the gene encoding the mouse acid labile subunit of the insulin-like growth factor binding complex. Proc Natl Acad Sci USA. 1996 Sep;93(19):10028-33.
76 Janosi JB, Ramsland PA, Mott MR, Firth SM, Baxter RC, Delhanty PJ. The acid-labile subunit of the serum insulin-like growth factor-binding protein complexes. Structural determination by molecular modeling and electron microscopy. J Biol Chem. 1999 Aug;274(33):23328-32.

77 Zaidman VE. Analysis of acid-labile subunit and its usefulness in pediatrics. Arch Argent Pediatr. 2017 Aug;115(4):391-8.

78 David A, Kelley LA, Sternberg MJ. A new structural model of the acid-labile subunit: pathogenetic mechanisms of short staturecausing mutations. J Mol Endocrinol. 2012 Oct;49(3):213-20.

79 Ooi GT, Cohen FJ, Tseng LY, Rechler MM, Boisclair YR. Growth hormone stimulates transcription of the gene encoding the acidlabile subunit (ALS) of the circulating insulinlike growth factor-binding protein complex and ALS promoter activity in rat liver. Mol Endocrinol. 1997 Jun;11(7):997-1007.

80 Renes JS, van Doorn J, Breukhoven PE, Lem AJ, de Ridder MA, Hokken-Koelega AC. Acid-labile subunit levels and the association with response to growth hormone treatment in short children born small for gestational age. Horm Res Paediatr. 2014;81(2):126-32.

81 Domené HM, Bengolea SV, Martínez AS, Ropelato MG, Pennisi P, Scaglia P, et al. Deficiency of the circulating insulin-like growth factor system associated with inactivation of the acid-labile subunit gene. N Engl J Med. 2004 Feb;350(6):570-7.

82 Fofanova-Gambetti OV, Hwa V, Kirsch S, Pihoker C, Chiu HK, Högler W, et al. Three novel IGFALS gene mutations resulting in total ALS and severe circulating IGF-I/IGFBP-3 deficiency in children of different ethnic origins. Horm Res. 2009;71(2):100-10.

83 van Duyvenvoorde HA, Kempers MJ, Twickler TB, van Doorn J, Gerver WJ, Noordam C, et al. Homozygous and heterozygous expression of a novel mutation of the acid-labile subunit. Eur J Endocrinol. 2008 Aug;159(2):113-20.

84 Heath KE, Argente J, Barrios V, Pozo J, DíazGonzález F, Martos-Moreno GA, et al. Primary acid-labile subunit deficiency due to recessive IGFALS mutations results in postnatal growth deficit associated with low circulating insulin growth factor (IGF)-I, IGF binding protein-3 levels, and hyperinsulinemia. J Clin Endocrinol Metab. 2008 May;93(5):1616-24.

85 Hwa V, Haeusler G, Pratt KL, Little BM, Frisch H, Koller D, et al. Total absence of functional acid labile subunit, resulting in severe insulin-like growth factor deficiency and moderate growth failure. J Clin Endocrinol Metab. 2006 May;91(5):1826-31.

86 Domené HM, Hwa V, Argente J, Wit JM, Camacho-Hübner C, Jasper HG, et al.; International ALS Collaborative Group. Human acid-labile subunit deficiency: clinical, endocrine and metabolic consequences. Horm Res. 2009;72(3):129-41.

87 Işık E, Haliloglu B, van Doorn J, Demirbilek $\mathrm{H}$, Scheltinga SA, Losekoot M, et al. Clinical and biochemical characteristics and bone mineral density of homozygous, compound heterozygous and heterozygous carriers of three novel IGFALS mutations. Eur J Endocrinol. 2017 Jun;176(6):657-67.

88 Fofanova-Gambetti OV, Hwa V, Wit JM, Domene HM, Argente J, Bang P, et al. Impact of heterozygosity for acid-labile subunit (IGFALS) gene mutations on stature: results from the international acid-labile subunit consortium. J Clin Endocrinol Metab. 2010 Sep;95(9):4184-91

89 Domené HM, Scaglia PA, Martínez AS, Keselman AC, Karabatas LM, Pipman VR, et al. Heterozygous IGFALS gene variants in idiopathic short stature and normal children: impact on height and the IGF system. Horm Res Paediatr. 2013;80(6):413-23.

90 Twigg SM, Baxter RC. Insulin-like growth factor (IGF)-binding protein 5 forms an alternative ternary complex with IGFs and the acid-labile subunit. J Biol Chem. 1998 Mar; 273(11):6074-9.

91 Baxter RC. Characterization of the acid-labile subunit of the growth hormone-dependent insulin-like growth factor binding protein complex. J Clin Endocrinol Metab. 1988 Aug; 67(2):265-72.

92 Khosravi MJ, Diamandi A, Mistry J, Krishna RG, Khare A. Acid-labile subunit of human insulin-like growth factor-binding protein complex: measurement, molecular, and clinical evaluation. J Clin Endocrinol Metab. 1997 Dec;82(12):3944-51.

93 Suikkari AM, Baxter RC. Insulin-like growth factor (IGF) binding protein-3 in pregnancy serum binds native IGF-I but not iodo-IGF-I. J Clin Endocrinol Metab. 1991 Dec;73(6): 1377-9.

94 Blat C, Villaudy J, Binoux M. In vivo proteolysis of serum insulin-like growth factor (IGF) binding protein-3 results in increased availability of IGF to target cells. J Clin Invest. 1994 May;93(5):2286-90.

95 Rajah R, Katz L, Nunn S, Solberg P, Beers T, Cohen P. Insulin-like growth factor binding protein (IGFBP) proteases: functional regulators of cell growth. Prog Growth Factor Res. 1995;6(2-4):273-84.

96 Argente J, Chowen JA, Pérez-Jurado LA, Frystyk J, Oxvig C. One level up: abnormal proteolytic regulation of IGF activity plays a role in human pathophysiology. EMBO Mol Med. 2017 Oct;9(10):1338-45.

97 Bang P. Serum proteolysis of IGFBP-3. Prog Growth Factor Res. 1995;6(2-4):285-92.

98 Kløverpris S, Mikkelsen JH, Pedersen JH, Jepsen MR, Laursen LS, Petersen SV, et al. Stanniocalcin-1 Potently Inhibits the Proteolytic Activity of the Metalloproteinase Pregnancyassociated Plasma Protein-A. J Biol Chem. 2015 Sep;290(36):21915-24.

99 Fujimoto M, Hwa V, Dauber A. Novel Modulators of the Growth Hormone - Insulin-Like Growth Factor Axis: Pregnancy-Associated Plasma Protein-A2 and Stanniocalcin-2. J Clin Res Pediatr Endocrinol. 2017 Dec;9 Suppl 2:1-8. 
100 Hossenlopp P, Segovia B, Lassarre C, Roghani M, Bredon M, Binoux M. Evidence of enzymatic degradation of insulin-like growth factor-binding proteins in the $150 \mathrm{~K}$ complex during pregnancy. J Clin Endocrinol Metab. 1990 Oct;71(4):797-805.

101 Giudice LC, Farrell EM, Pham H, Lamson G, Rosenfeld RG. Insulin-like growth factor binding proteins in maternal serum throughout gestation and in the puerperium: effects of a pregnancy-associated serum protease activity. J Clin Endocrinol Metab. 1990 Oct;71(4):806-16.

102 Hasegawa Y, Hasegawa T, Koni H, Aso T, Tanaka N, Kotoh S, et al. Proteolytic activity of IGFBP-3 in various clinical conditions during childhood studied by means of western immunoblotting. Endocr J. 1995 Aug; 42(4):569-76.

103 Cianfarani S, Germani D, Rossi P, Rossi L, Germani A, Ossicini C, et al. Intrauterine growth retardation: evidence for the activation of the insulin-like growth factor (IGF)related growth-promoting machinery and the presence of a cation-independent IGF binding protein- 3 proteolytic activity by two months of life. Pediatr Res. 1998 Sep;44(3): 374-80.

104 Cianfarani S, Liguori A, Boemi S, Maghnie $\mathrm{M}$, Iughetti L, Wasniewska M, et al. Inaccuracy of insulin-like growth factor (IGF) binding protein (IGFBP)-3 assessment in the diagnosis of growth hormone (GH) deficiency from childhood to young adulthood: association to low GH dependency of IGF-II and presence of circulating IGFBP-3 18-kilodalton fragment. J Clin Endocrinol Metab. 2005 Nov;90(11):6028-34.

105 Dauber A, Muñoz-Calvo MT, Barrios V, Domené HM, Kloverpris S, Serra-Juhé C, et al. Mutations in pregnancy-associated plasma protein $\mathrm{A} 2$ cause short stature due to low IGF-I availability. EMBO Mol Med. 2016 Apr;8(4):363-74.

106 Muñoz-Calvo MT, Barrios V, Pozo J, Chowen JA, Martos-Moreno GA, Hawkins F, et al. Treatment With Recombinant Human Insulin-Like Growth Factor-1 Improves Growth in Patients With PAPP-A2 Deficiency. J Clin Endocrinol Metab. 2016 Nov; 101(11):3879-83.

107 Van Pareren Y, Mulder P, Houdijk M, Jansen M, Reeser M, Hokken-Koelega A. Adult height after long-term, continuous growth hormone $(\mathrm{GH})$ treatment in short children born small for gestational age: results of a randomized, double-blind, dose-response GH trial. J Clin Endocrinol Metab. 2003 Aug;88(8):3584-90.

108 Carel JC, Chatelain P, Rochiccioli P, Chaussain JL. Improvement in adult height after growth hormone treatment in adolescents with short stature born small for gestational age: results of a randomized controlled study. J Clin Endocrinol Metab. 2003 Apr; 88(4):1587-93.

109 Dahlgren J, Wikland KA; Swedish Study Group for Growth Hormone Treatment. Final height in short children born small for gestational age treated with growth hormone. Pediatr Res. 2005 Feb;57(2): 216-22.

110 Lem AJ, van der Kaay DC, de Ridder MA, Bakker-van Waarde WM, van der Hulst FJ, Mulder JC, et al. Adult height in short children born SGA treated with growth hormone and gonadotropin releasing hormone analog: results of a randomized, dose-response GH trial. J Clin Endocrinol Metab. 2012 Nov;97(11):4096-105.

111 Renes JS, Willemsen RH, Mulder JC, Bakker-van Waarde WM, Rotteveel J, Oostdijk $\mathrm{W}$, et al. New insights into factors influencing adult height in short SGA children: results of a large multicentre growth hormone trial. Clin Endocrinol (Oxf). 2015 Jun;82(6): 854-61.

112 Cirillo F, Lazzeroni P, Catellani C, Sartori C, Amarri S, Street ME. MicroRNAs link chronic inflammation in childhood to growth impairment and insulin-resistance. Cytokine Growth Factor Rev. 2018 Feb;39: $1-18$.

113 Wong SC, Dobie R, Altowati MA, Werther GA, Farquharson C, Ahmed SF. Growth and the Growth Hormone-Insulin Like Growth Factor 1 Axis in Children With Chronic Inflammation: Current Evidence, Gaps in Knowledge, and Future Directions. Endocr Rev. 2016 Feb;37(1):62-110.

114 Street ME, Seghini P, Fieni S, Ziveri MA, Volta C, Martorana D, et al. Changes in interleukin- 6 and IGF system and their relationships in placenta and cord blood in newborns with fetal growth restriction compared with controls. Eur J Endocrinol. 2006 Oct;155(4):56774.

115 Karlberg JP, Albertsson-Wikland K, Kwan EY, Lam BC, Low LC. The timing of early postnatal catch-up growth in normal, fullterm infants born short for gestational age. Horm Res. 1997;48 Suppl 1:17-24.
116 de Ridder MA, Stijnen T, Hokken-Koelega AC. Prediction model for adult height of small for gestational age children at the start of growth hormone treatment. J Clin Endocrinol Metab. 2008 Feb;93(2):477-83.

117 Ranke MB, Lindberg A; KIGS International Board. Height at start, first-year growth response and cause of shortness at birth are major determinants of adult height outcomes of short children born small for gestational age and Silver-Russell syndrome treated with growth hormone: analysis of data from KIGS. Horm Res Paediatr. 2010; 74(4):259-66.

118 Ueki I, Giesy SL, Harvatine KJ, Kim JW, Boisclair YR. The acid-labile subunit is required for full effects of exogenous growth hormone on growth and carbohydrate metabolism. Endocrinology. 2009 Jul;150(7): 3145-52.

119 Koedam JA, Hoogerbrugge CM, van BuulOffers SC. Insulin-like growth factor-binding protein-3 protease activity in Snell normal and Pit-1 deficient dwarf mice. J Endocrinol. 1998 May;157(2):295-303.

120 Binoux M, Lalou C, Lassarre C, Blat C, Hossenlopp P. Limited proteolysis of insulinlike growth factor binding protein-3 (IGFBP-3): a physiological mechanism in the regulation of IGF bioavailability. Adv Exp Med Biol. 1993;343:293-300.

121 Fielder PJ, Mortensen DL, Mallet P, Carlsson B, Baxter RC, Clark RG. Differential longterm effects of insulin-like growth factor-I (IGF-I) growth hormone (GH), and IGF-I plus GH on body growth and IGF binding proteins in hypophysectomized rats. Endocrinology. 1996 May;137(5):1913-20.

122 de Zegher F, Maes M, Gargosky SE, Heinrichs C, Du Caju MV, Thiry G, et al. Highdose growth hormone treatment of short children born small for gestational age. J Clin Endocrinol Metab. 1996 May;81(5): 1887-92.

123 Jenkins PJ, Mukherjee A, Shalet SM. Does growth hormone cause cancer? Clin Endocrinol (Oxf). 2006 Feb;64(2):115-21.

124 Bakker NE, van Doorn J, Renes JS, Donker GH, Hokken-Koelega AC. IGF-1 Levels, Complex Formation, and IGF Bioactivity in Growth Hormone-Treated Children With Prader-Willi Syndrome. J Clin Endocrinol Metab. 2015 Aug;100(8):3041-9.

125 Janssen JA. Insulin-like growth factor I: pros and cons of a bioassay. Horm Res Paediatr. 2011;76(s1 Suppl 1):106-10.
The GH-IGF System in Short Children Born SGA
Horm Res Paediatr 2019;92:15-27

DOI: $10.1159 / 000502739$ 